\title{
Peertechz
}

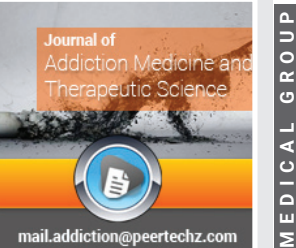

\section{T Lymphocytes and Cytokines: Earlier time to peak indicates better prognosis in COVID-19 patients?}

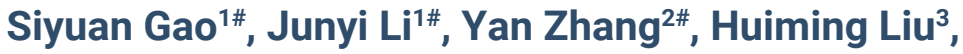 Xiaodong Yang ${ }^{1}$, Ting Jia ${ }^{1}$, Fangrong Zhang ${ }^{1}$, Xiuling Zhang ${ }^{1}$ and Jianpeng Gao ${ }^{1 *}$}

'Liver Center, The Third People's Hospital of Kunming, Yunnan, China 2Department of Disease Prevention and Control, The Third People's Hospital of Kunming, Yunnan, China

${ }^{3}$ Department of Infectious Diseases, Hospital of Dongchuan District, Kunming, Yunnan, China \#Equally Contributed Towards the Manuscript

Received: 06 April, 2021

Accepted: 23 April, 2021

Published: 26 April, 2021

*Corresponding author: Jianpeng Gao, Liver Center The Third People's Hospital of Kunming, Yunnan, China, Tel: +8613608855109; E-mail: gaojn1@sina.com ORCID: https://orcid.org/0000-0001-9273-0817 Keywords: COVID-19; T Lymphocyte subgroups; Cytokines; Time to peak

https://www.peertechzpublications.com

Check for updates

\section{Abstract}

Aims: To explore the changes of cytokines and T lymphocyte subgroups in COVID-19 patients, to find the turning point to severe clinical course of patients, to timely intervene, and to reduce the severity.

Methods: Thirty-nine patients with COVID-19 admitted to Third People's Hospital of Kunming from January 31, 2020 to March 2, 2020 were divided into 3 groups: mild, common and severe/critical according to 'Clinical Protocol for COVID-19, 8th Edition' (National Health Commission of People's Republic of China). The changes of serum T lymphocyte subgroups and cytokines level during hospitalization were monitored and statistically analyzed. The difference was considered statistically significant when $p<0.05$.

Results: 39 patients with COVID-19 were $41.51 \pm 19.03$ years old, 18 of them were male (46.2\%).8 patients (20.5\%) were classified as mild group, 10 patients (25.6\%) were classified as common group, 21 patients (53.8\%) were classified as severe/critical group. The hospitalization days were $17.51 \pm 6.19$ days, and the nucleic acid seroconversion days from positive to negative were $11.41 \pm 6.77$ days. Comparison of $\mathrm{T}$ lymphocyte subgroups in patients with different clinical classifications showed that $\mathrm{T}$ cell count and CD4/CD8 ${ }^{+} \mathrm{T}$ cell counts were different among different clinical classifications $(p<0.05)$. In pairwise comparison, the count of lymphocyte subgroups in severe/critical group patients was significantly lower than that in mild and common groups. Intra-group Comparison showed that, IL-2, IL-8, IL-12p70 and IL-5 examinations had significant statistical differences at different examination time points, but the effects of the above indicators on clinical classification would not change with time. According to develop trends, lymphocytes increased in patients of three clinical groups after treatment, the increase trends were obvious especially in severe/critical group patients. The OR value calculated by Logistics model showed that the probability of severe/critical disease was 1.276 times higher for each day increase of $\mathrm{T}$ cell time to peak (95\%Cl: 1.039-1.569), $\chi 2=5.379, p=0.02$. The probability of severe/critical disease was 1.408 times $(95 \% \mathrm{Cl}: 1.066-1.859)$ with each day increase of IL $1 \beta$ time to peak, $\chi 2=5.824, p=0.016$. Independent sample $t$ test showed that in CD4+T cells, IL-1 $\beta$, IL-2, IL-8, IL-12p70, IL-17A, IFN- $\gamma$, TNF-a and other detection indicators, the time to peak of the above indicators in the fast seroconversion group was significantly shorter than that in slow seroconversion group.

Conclusions: The early peak, timely decrease of cytokines and T cell counts in COVID-19 patients has a positive effect on prognosis. Cytokines and T cell counts should be closely monitored in COVID-19 patients. 
Since December 2019, a novel coronavirus was first discovered in Wuhan, China, new Coronavirus Disease (COVID-19) has been a worldwide disease. Up to March, there have been more than 128 million confirmed cases of COVID-19 globally, the mortality rate is about $2.2 \%$ [1]. At the beginning of the disease, acute respiratory symptoms are commonly seen, while some patients would progress to Acute Respiratory Distress Syndrome (ARDS), in some of them, respiratory failure may appear. With the development of COVID-19 immunological research, many researchers have elaborated on the immunological characteristics of COVID-19. Huang, et al. compared the clinical manifestations and laboratory indicators of COVID-19 ICU patients and non-ICU patients, and found that the serum levels of serum cytokines such as IL-2, IL-7, IL-10 and TNF- $\alpha$ in ICU patients were significantly higher than those in non-ICU patients. The serum levels of $\mathrm{CD}_{4}{ }^{+} \mathrm{T}$ cells, $\mathrm{CD}^{+} \mathrm{T}$ cells and Natural Killer (NK) cells in critical patients were lower than those in mild patients, suggesting that critical patients may have significant immune cell depletion [1]. In a variety of viral diseases, it has been found that the imbalance of cytokines and the decrease or exhaustion of $\mathrm{T}$ cell count play important roles in the severity of the disease [2]. Above studies, however, were merely descriptive studies on cytokines and lymphocytes of COVID-19 patients. Few involved the time point of transferring from mild disease to severe disease.Our study aims to explore the relationship between cytokines and $\mathrm{T}$ lymphocyte subgroups, to find the turning point of mild to severe clinical course, to block the severity of disease as early as possible, to intervene in time, and to explore the clinical possibility of reducing severe clinical course.

\section{Materials and methods}

\section{Patients}

The study was approved by the ethics committee of the Third People's Hospital of Kunming, following the principles of Helsinki declaration. 39 patients admitted in Third People's Hospital of Kunming with COVID-19 were collected since January $31^{\text {st }}$ to March $2^{\text {nd }}$ retrospectively. Informed consent were signed by all the 39 patients or their guardians.

\section{Clinical classifications of disease severity}

All the patients were diagnosed according to "Clinical Protocol for COVID-19, 8th Edition", National Health Commission of People's Republic of China [3]. They were classified as: (1) Mild: mild clinical symptoms, no pneumonia in imaging; (2)Common: fever, respiratory symptoms, imaging findings of pneumonia; (3)Severe: any of the following: (1) Shortness of breath, respiratory rate $(\mathrm{RR}) \geq 30$ times/ min; (2) in resting state,oxygen saturation $\leq 93 \%$; (3) $\mathrm{PaO}_{2} /$ $\mathrm{FiO}_{2} \leq 300 \mathrm{mmHg} \quad(1 \mathrm{mmHg}=0.133 \mathrm{kpa})$; High altitudes areas (over $1000 \mathrm{~m}$ ) should correct for $\mathrm{PaO} 2 / \mathrm{FiO} 2$ according to the following formula: $\mathrm{PaO}_{2} / \mathrm{FiO}_{2} \times[760 /$ atmospheric pressure (mmHg)]. 44progressive exacerbation of clinical symptoms and pulmonary imaging showing significant progression of $>50 \%$ within $24-48$ hours. (4) Critical:One of the following conditions: A. Respiratory failure requiring mechanical ventilation; B. Shock; C. complected with other organ failures required for ICU monitoring and treatments.

\section{Data collection}

The basic data of 39 COVID-19 patients, including age, gender, diagnosis, days of hospital stay, and days of nucleic acid seroconversion (from positive to negative) were collected. $T$ cell subgroups and cytokine values were dynamically monitored at different time points during patients' hospitalization. All the laboratory tests were carried out by Clinical Laboratory of the Third People's Hospital of Kunming.

\section{Test methods}

BD company FACSCANTO II flow cytometer was used for flow fluorescence detection. The T-lymphocyte subgroups detection reagent was the BD Mult-Test IMK Kit by BD Company, and the cytokine detection reagent was the 12 Cytokine Detection Kits provided by Jiangxi Saiji Biotechnology Co., Ltd. Bio-Rad Real-time fluorescence quantitative PCR was used for 2019 novel coronavirus (2019-nCoV) RNA detection. The reagent was 2019-nCoV nucleic acid detection kit by Shanghai BioGerm Medical Technology Co., Ltd.

\section{Statistic analysis}

GraphPad Prism 8.02 was used for plotting, and IBM SPSS Data Editor Version 23.0 was used for statistical analysis. Variables of normal distribution are represented by mean \pm standard deviation, the variables of non- normal distribution are represented by median, and the classified variables are represented by frequency and rate (\%). Repeated measurement ANOVA was used. If the repeated measurement ANOVA did not satisfy the spherical symmetry test, the correction results of Greenhouse-Geisser were used. The difference was considered statistically significant when $p<0.05$.

\section{Results}

\section{Basic characteristics of patients}

Among the 39 patients with COVID-19 in our hospital, most of them were female, with the age ranging from 3-79 years old.There were 8 cases of mild type, 10 cases of common type and 21 cases of severe and critical type. Days of nucleic acid seroconversion is the days from admission to the time of nucleic acid negative collected by throat swab (Table 1).

\section{Results of sphericity test}

Results of Mauchly's Test of Sphericity for all indicators in the COVID-19 patient's laboratory (Table 2). The results of Mauchly's Test of Sphericity showed that $p>0.05$, which

\begin{tabular}{|c|c|c|}
\hline Gender (male\%) & & $18(46.2 \%)$ \\
\hline Age (years old) & & $3-79(41.51 \pm 19.03)$ \\
\hline \multirow[t]{3}{*}{ Clinical Classifications } & Mild Group & $8(20.5 \%)$ \\
\hline & Common Group & $10(25.6 \%)$ \\
\hline & Severe and Critical Group & $21(53.8 \%)$ \\
\hline Days in Hospital & & $6-31(17.51 \pm 6.19)$ \\
\hline $\begin{array}{l}\text { Days of Nucleic Acid } \\
\text { Seroconversion }\end{array}$ & & $1-24(11.41 \pm 6.77)$ \\
\hline
\end{tabular}

Citation: Gao S, Li J, Zhang Y, Liu H, Gao J, et al. (2021) T Lymphocytes and Cytokines: Earlier time to peak indicates better prognosis in COVID-19 patients? J Addict Med Ther Sci 7(1): 013-019. DOI: https://dx.doi.org/10.17352/2455-3484.000050 
satisfied the hypothesis of spherical symmetry. When $p<$ 0.05 dissatisfied with the hypothesis o spherical symmetry, Greenhouse-Geisser's correction results were used.

\section{Results of analysis of repeated measures ANOVA for different clinical classifications of patients' laboratory indicators.}

I. Intergroup comparison: Analysis of variance $(p<0.05)$ suggested that there were differences in $\mathrm{T}$ cell count and $\mathrm{CD} 4 / \mathrm{CD}^{+} \mathrm{T}$ cell count among different clinical classifications (Table 3). Further pairwise comparison results are shown in Table 4 .

$\mathrm{T}$ cell count is significantly lower in severe/critical group compared with in mild $(\mathrm{p}=0.033)$ and common group $(\mathrm{p}=$ $0.001)$;

$\mathrm{CD}_{4}{ }^{+\mathrm{T}}$ cell count is significantly lower in severe/critical group compared with in common group $(p=0.003)$;

$\mathrm{CD}^{+} \mathrm{T}$ cell count is significantly lower in severe/critical group compared with in mild $(\mathrm{p}=0.003)$ and common group $(\mathrm{p}=0.003)$;

It can be seen that the total number of $\mathrm{T}$ lymphocyte, $\mathrm{CD}_{4}{ }^{+} \mathrm{T}$ and $\mathrm{CD} 8{ }^{+} \mathrm{T}$ cell counts in severe/critical patients were remarkable lower than those in mild and normal patients.

II. Intra-group Comparison: Time for IL-2, IL-8, IL12 p70 and IL-5 p $<0.05$, Time*Classification $\mathrm{p}>0.05$. It suggested that IL-2, IL-8, IL-12p70 and IL-5 examinations had significant statistical differences at different examination time points, but the effects of the above indicators on classification would not change with time.

\section{Development trends for CD3+ Cell /CD4+/CD8+ T Cell in different clinical classifications}

The horizontal axis shows the times of examinations

Table 2: Mauchly's Test of Sphericity Results of Patients' Laboratory Indicators. Indicators Mauchly's W Appro Chi-square df sig. Greenhouse-Geisse

\begin{tabular}{|c|c|c|c|c|c|}
\hline T Cell & 0.606 & 14.376 & 5 & 0.013 & 0.798 \\
\hline CD4 ${ }^{+}$T Cell & 0.727 & 9.176 & 5 & 0.102 & 0.827 \\
\hline CD8 ${ }^{+}$T Cell & 0.661 & 11.898 & 5 & 0.036 & 0.822 \\
\hline IL-1 & 0.073 & 20.200 & 5 & 0.001 & 0.638 \\
\hline IL-2 & 0.421 & 6.687 & 5 & 0.248 & 0.720 \\
\hline IL-4 & 0.547 & 4.665 & 5 & 0.461 & 0.785 \\
\hline IL-5 & 0.407 & 6.935 & 5 & 0.229 & 0.672 \\
\hline IL-6 & 0.079 & 19.605 & 5 & 0.002 & 0.430 \\
\hline IL-8 & 0.126 & 15.991 & 5 & 0.007 & 0.658 \\
\hline IL-10 & 0.658 & 3.227 & 5 & 0.667 & 0.810 \\
\hline IL-12p70 & 0.427 & 6.579 & 5 & 0.257 & 0.741 \\
\hline IL-17A & 0.291 & 9.527 & 5 & 0.092 & 0.633 \\
\hline IFN-y & 0.361 & 7.868 & 5 & 0.167 & 0.744 \\
\hline IFN-a & 0.000 & 62.175 & 5 & 0.000 & 0.339 \\
\hline TNF-a & 0.271 & 10.078 & 5 & 0.075 & 0.575 \\
\hline
\end{tabular}

during the patients' hospitalization, and the vertical axis shows the levels of $\mathrm{T}$ lymphocyte, $\mathrm{CD}_{4}{ }^{+}$and $\mathrm{CD} 8^{+} \mathrm{T}$ cell count. As can be seen from Figures 1,2, T cell count in mild group and common group patients increased slowly over time, while those in severe/critical group increased significantly over time, especially in the third and fourth examinations compared with the second examination. $\mathrm{CD}_{4}^{+\mathrm{T}}$ cell count in mild group and common group patients increased slowly with time, and the trend was relatively gentle. $\mathrm{CD}_{4}{ }^{+\mathrm{T}}$ cell count in severe/critical patients increased significantly with time, and the elevation was more obvious in the third and fourth examinations than in the second examination. CD8+T cell count also increased significantly in severe/critical patients compared with mild and common patients during treatment.

\section{Results of analysis of single factor for different clinical classifications}

The T lymphocyte subgroups and the time to peak of cytokines collected were analyzed by one-way ANOVA according to the clinical classification, as shown in Table 5. At the same time, multiple linear tests were conducted for all indicators in the table with $p<0.05$, and finally, the days of nucleic acid seroconversion, the time to peak of $\mathrm{T}$ lymphocytes ( $\mathrm{CD} 3^{+}$cells), the time to peak of IL1 $\beta$ and the time to peak of IL17A were included in the logistics regression statistics (Table $6)$.

Logistics analysis results showed that parallel test was satisfied $\left(\chi_{2}=7.837 \mathrm{p}=0.098\right)$; There is proportional advantage hypothesis; Deviance goodness-of-fit test showed that the model could fit well $\left(\chi_{2}=45.127, \mathrm{pbn}=0.991\right)$. This model was superior to the model with constant only $\left(\chi_{2}=45.127, \mathrm{p}<0.001\right)$.

As can be seen from Table 6, the time to peak of T cells (CD3+ cells) was $p=0.02$ and the time to peak of IL- $1 \beta$ was $p=0.016$, which were statistically significant and could be included in the logistics model. It is suggested that, in mild and common group vs severe/critical group, $\mathrm{T}$ cell time to peak and IL-1 $\beta$ time to peak had influence on clinical classifications. Meanwhile, the OR value showed that the probability of progressing to severe/ critical disease was 1.276 times (95\%CI: 1.039-1.569) with the increase of $\mathrm{T}$ cell time to peak $\left(\chi_{2}=5.379, \mathrm{p}=0.02\right)$. The probability of progressing to severe/critical disease was 1.408 times (95\%CI: 1.066-1.859) with each day increase of IL1 $\beta$ time to peak $(\chi 2=5.824, \mathrm{p}=0.016)$.

\section{Comparison of the differences between the time to peak of cytokines and T lymphocyte subgroups}

Independent sample $\mathrm{t}$ test was used to analyze whether there were differences in the time to peak, when cytokines value and $\mathrm{T}$ cell count reached the maximum between the fast nuleic acid seroconversion group and slow seroconversion group (Table 7). It can be seen that in $\mathrm{CD}_{4}{ }^{+} \mathrm{T}$ cells, IL-1 $\beta$, IL2, IL-8, IL-12p70, IL-17A, IFN- $\gamma$, TNF- $\alpha$ and other detection indicators, the time to peak of the above indicators in the fast seroconversion group was significantly shorter than that in slow seroconversion group, that is, faster time to peak of the above indicators related to faster recovery.

Citation: Gao S, Li J, Zhang Y, Liu H, Gao J, et al. (2021) T Lymphocytes and Cytokines: Earlier time to peak indicates better prognosis in COVID-19 patients? J Addict Med Ther Sci 7(1): 013-019. DOI: https://dx.doi.org/10.17352/2455-3484.000050 
Table 3: Results of Analysis of Repeated Measures ANOVA for Different Classifications of COVID-19 Patients Laboratory Indicators.

\begin{tabular}{|c|c|c|c|c|c|c|}
\hline Indicators & Source & Type III sum of Squares & df & Mean Squares & $\mathbf{F}$ & sig. \\
\hline \multirow{3}{*}{$\mathrm{CD}^{+}$cell $(\# / \mathrm{ul})$} & Classification & 5428471.702 & 2 & 2714235.851 & 7.789 & 0.002 \\
\hline & Time & 431339.213 & 2.395 & 180106.572 & 2.698 & 0.064 \\
\hline & Time*Classification & 647274.241 & 4.790 & 135135.343 & 2.024 & 0.088 \\
\hline \multirow{3}{*}{ CD4 ${ }^{+} \mathrm{T}$ cell $(\# / \mathrm{ul})$} & Classification & 928441.455 & 2 & 464220.727 & 8.797 & 0.001 \\
\hline & Time & 35284.493 & 3 & 11761.498 & 1.479 & 0.226 \\
\hline & Time*Classification & 104564.728 & 6 & 17427.455 & 2.191 & 0.051 \\
\hline \multirow{3}{*}{ CD8 ${ }^{+} \mathrm{T}$ cell (\#/ul) } & Classification & 1778700.931 & 2 & 889350.466 & 5.140 & 0.012 \\
\hline & Time & 199738.030 & 3 & 66579.343 & 2.705 & 0.050 \\
\hline & Time*Classification & 237864.583 & 6 & 39644.097 & 1.610 & 0.153 \\
\hline \multirow{3}{*}{ IL-1 } & Classification & 9.132 & 1 & 9.132 & 0.186 & 0.677 \\
\hline & Time & 18.892 & 1.913 & 9.874 & 3.066 & 0.074 \\
\hline & Time*Classification & 5.276 & 1.913 & 2.757 & 0.856 & 0.438 \\
\hline \multirow{3}{*}{ IL-2 } & Classification & 0.712 & 1 & .712 & 0.135 & 0.721 \\
\hline & Time & 1.699 & 3 & 0.566 & 4.142 & 0.015 \\
\hline & Time*Classification & 1.144 & 3 & 0.381 & 2.788 & 0.060 \\
\hline \multirow{3}{*}{ IL-4 } & Classification & 8.835 & 1 & 8.835 & 2.643 & 0.138 \\
\hline & Time & 0.731 & 3 & 0.244 & 1.303 & 0.294 \\
\hline & Time*Classification & 1.707 & 2.355 & 0.725 & 3.040 & 0.062 \\
\hline \multirow{3}{*}{ IL-5 } & Classification & 0.412 & 1 & 0.412 & 0.514 & 0.492 \\
\hline & Time & 0.694 & 3 & 0.231 & 3.069 & 0.045 \\
\hline & Time*Classification & 0.169 & 3 & 0.056 & 0.746 & 0.534 \\
\hline \multirow[t]{3}{*}{ IL-6 } & Classification & 0.287 & 1 & 0.287 & 0.016 & 0.902 \\
\hline & Time & 0.885 & 1.291 & 0.686 & 0.055 & 0.875 \\
\hline & Time*Classification & 37.388 & 1.291 & 28.969 & 2.339 & 0.150 \\
\hline \multirow[t]{3}{*}{ IL-8 } & Classification & 64.060 & 1 & 64.060 & 0.142 & 0.715 \\
\hline & Time & 6961.616 & 1.973 & 3528.994 & 4.087 & 0.035 \\
\hline & Time*Classification & 437.890 & 1.973 & 221.976 & 0.257 & 0.773 \\
\hline \multirow[t]{3}{*}{ IL-10 } & Classification & 0.847 & 1 & 0.847 & 0.033 & 0.861 \\
\hline & Time & 3.465 & 3 & 1.155 & 0.936 & 0.437 \\
\hline & Time*Classification & 0.397 & 3 & 0.132 & 0.107 & 0.955 \\
\hline \multirow[t]{3}{*}{ IL-12p70 } & Classification & 44.217 & 1 & 44.217 & 2.836 & 0.126 \\
\hline & Time & 14.976 & 3 & 4.992 & 6.458 & 0.002 \\
\hline & Time*Classification & 5.293 & 3 & 1.764 & 2.282 & 0.102 \\
\hline \multirow[t]{3}{*}{ IL-17A } & Classification & 1312.225 & 1 & 1312.225 & 0.524 & 0.487 \\
\hline & Time & 1345.865 & 3 & 448.622 & 1.907 & 0.152 \\
\hline & Time*Classification & 394.612 & 3 & 131.537 & 0.559 & 0.647 \\
\hline \multirow[t]{3}{*}{ IFN-y } & Classification & 0.276 & 1 & 0.276 & 0.001 & 0.979 \\
\hline & Time & 131.474 & 3 & 43.825 & 1.535 & 0.228 \\
\hline & Time*Classification & 53.051 & 3 & 17.684 & 0.619 & 0.609 \\
\hline \multirow[t]{3}{*}{ IFN-a } & Classification & 500.336 & 1 & 500.336 & 0.450 & 0.519 \\
\hline & Time & 1501.757 & 1.016 & 1477.983 & 0.855 & 0.381 \\
\hline & Time*Classification & 2114.547 & 1.016 & 2081.071 & 1.204 & 0.302 \\
\hline \multirow[t]{3}{*}{ TNF-a } & Classification & 9.419 & 1 & 9.419 & 0.213 & 0.656 \\
\hline & Time & 6.449 & 3 & 2.150 & 2.663 & 0.068 \\
\hline & Time*Classification & 6.956 & 3 & 2.319 & 2.872 & 0.055 \\
\hline
\end{tabular}

Table 4: Multiple Comparison Results of $\mathrm{CD}^{+}$cell $/ \mathrm{CD} 4^{+} / \mathrm{CD} 8^{+} \mathrm{T}$ Cell Counts of Different Classifications.

\begin{tabular}{|l|c|c|c|c|c|c|}
\hline & \multicolumn{3}{|c|}{ Common Group } & \multicolumn{3}{c|}{ Severe/Critical Group } \\
\cline { 2 - 7 } & CD3 $^{+}$ & CD4 $^{*}$ & CD8 $^{+}$ & CD3 $^{+}$ & CD4 $^{*}$ & CD8 $^{+}$ \\
\hline Mild Group & 87.281 & 204.28 & 47.38 & $360.21^{*}$ & 71.76 & $156.29^{*}$ \\
\hline Common Group & & & & $477.50^{*}$ & $277.04^{*}$ & $156.29^{*}$ \\
\hline${ }^{*} p<0.05$ & & & & & & \\
\hline
\end{tabular}

\section{Discussion}

In the study, $\mathrm{T}$ cell count of COVID-19 patients with various clinical classifications were analyzed, and it was found that all $\mathrm{T}$ cell subgroups in severe/critical patients were lower than those in mild or common patients, which was consistent with the conclusions of previous other studies. Moreover, it is worth mentioning that our study is the first one to describe the immunological characteristics of COVID-19 patients in time dimension.

With the deepening of immunological studies on COVID-19 patients, it is the key point for the treatment to explore the changes of cytokines and $\mathrm{T}$ lymphocytes, timely find the changing point of severe clinical course of disease and timely intervene. As one of the important cells of the acquired immune system, T lymphocytes play important roles in all infectious diseases.T cell count is positively correlated with the disease prognosis [4]. As cytotoxic $\mathrm{T}$ cells, $\mathrm{CD} 8^{+} \mathrm{T}$ cells have a direct killing effect on virus-infected cells, and a significant decrease in $\mathrm{CD}^{+} \mathrm{T}$ cell levels can be seen in patients with COVID-19 $[5,6]$. Decrease in $\mathrm{T}$ cell count can be observed in the early stage of COVID-19 disease, and the decrease in T cell count is more 

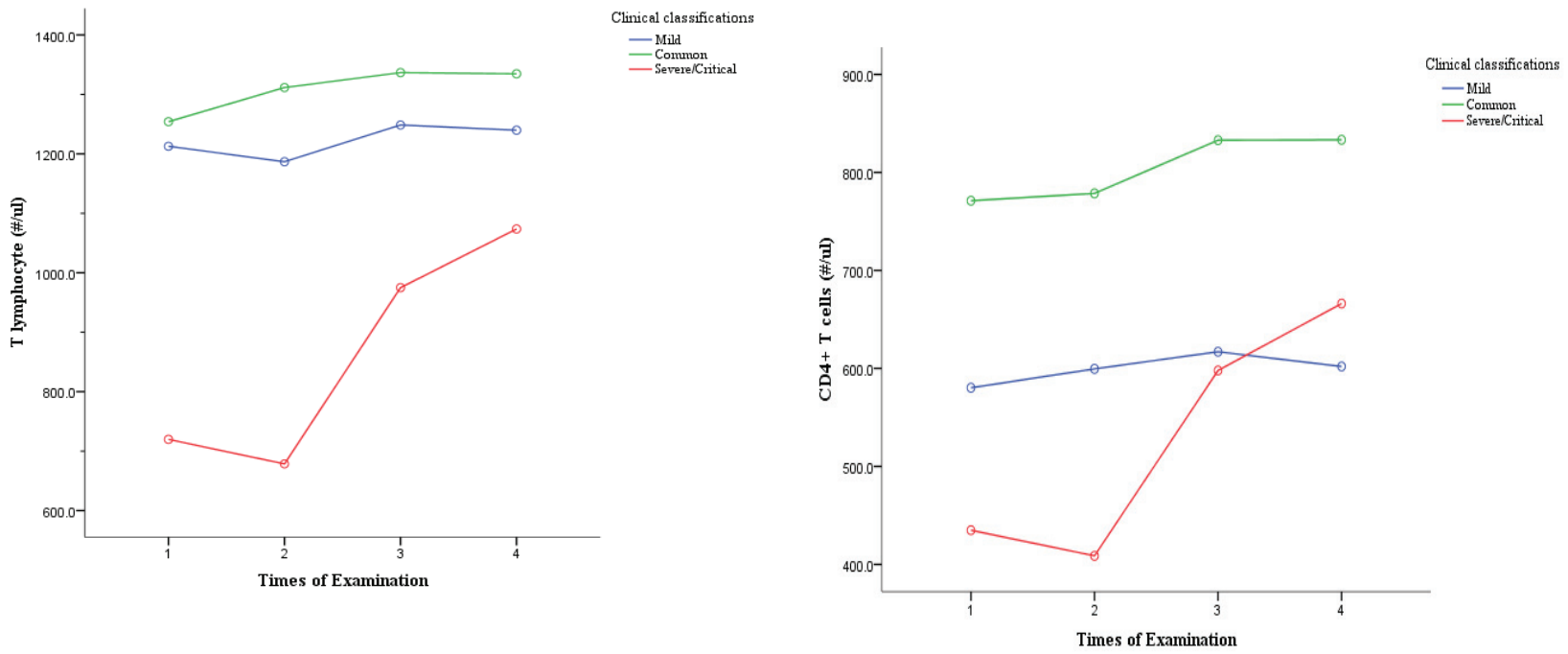

Figure 1: $\mathrm{CD}^{+}$(left) and CD4 $4^{+}$(right) T Cell Development Trends of Patients with Different Clinical Classifications of COVID-19.

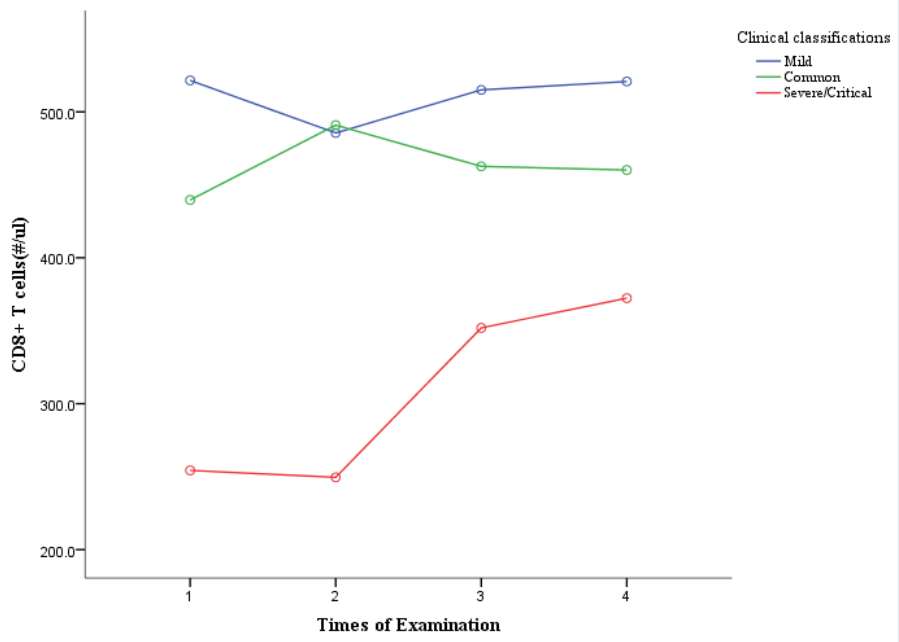

Figure 2: $\mathrm{CD}^{+} \mathrm{T}$ Cell Development Trends of Patients with Different Types of COVID-19.

significant in patients with severe disease than in patients with mild disease. In some critical patients, even, depletion of $\mathrm{T}$ lymphocyte may occur. As can be seen in other study, decrease in $\mathrm{CD}_{4}{ }^{+} \mathrm{T}$ cell counts is also common in severely ill patients [7]. We observed that, patients with severe/critical disease had significantly lower T cell, CD4 and CD8+T cell counts than patients with mild and common disease, which was consistent with the characteristics of patients with COVID-19 described by other researchers. According to develop trends described in our study, however, $\mathrm{T}$ lymphocytes, $\mathrm{CD}^{+} \mathrm{T}$ and $\mathrm{CD} 8^{+} \mathrm{T}$ cell counts have not decreased dramatically. Lymphocytes increased in patients of all three clinical groups after treatment, the increase trends were significant especially in severe/critical group patients. A possible explanation is, although there is a certain proportion of severe/critical patients, all patients got good prognosis after hospitalization. Again, the T cell count and its changing trend probably determine the progression and outcome of the patient's disease.

In our study, it was suggested that the possibility of severe/ critical patients was significantly increased with prolonged time to peak of T cell count and IL1 $\beta$ value. At the same time, the faster CD4, IL-1 $\beta$, IL-2, IL-8, IL-12p70, IL-17A, IFN- $\gamma$, TNF- $\alpha$ and other indicators reached the peak, the faster nucleic acid negatively seroconverse. Previous immunology studies on COVID-19 infection suggested that the virus produced two cytokine spikes after attacking the body. In the first stage, the natural immune system of the body activates type I interferon response and causes a small peak of cytokines. The second was a cytokines storm that dramatically worsened the symptoms [8]. Type I interferon response is an important mechanism of the innate immune system to protect the body against virus. It produces IL-1 $\beta, \mathrm{TNF}-\alpha, \mathrm{IL}-6$ and regulates the immune response of $\mathrm{T}$ cells to prevent the further amplification of the cytotoxic reaction [9]. In the process of respiratory virus

Table 5: Results of Analysis of Single Factor for Different Types of COVID-19 Laboratory Indicators.

\begin{tabular}{|c|c|c|c|c|}
\hline & M & SD & F & sig. \\
\hline Days in hospital & 9.692 & 6.9364 & 11.697 & $<0.001$ \\
\hline CD3 ${ }^{+}$T cell time to peak & 9.462 & 6.6207 & 5.520 & 0.008 \\
\hline CD4 ${ }^{+}$Tcell time to peak & 16.895 & 7.0779 & 5.284 & 0.010 \\
\hline CD8 ${ }^{+}$Tcell time to peak & 5.579 & 5.3858 & 4.136 & 0.024 \\
\hline IL-1 $\beta$ time to peak & 5.000 & 5.9729 & 12.396 & $<0.001$ \\
\hline IL-2 time to peak & 5.132 & 5.2152 & 1.383 & 0.264 \\
\hline IL-4 time to peak & 4.237 & 4.3086 & 0.968 & 0.390 \\
\hline IL-5 time to peak & 4.947 & 5.6614 & 0.767 & 0.472 \\
\hline IL-6 time to peak & 4.237 & 4.4505 & 0.404 & 0.671 \\
\hline IL-8 time to peak & 5.342 & 5.3790 & 2.017 & 0.148 \\
\hline IL-10 time to peak & 6.184 & 6.1065 & 0.507 & 0.607 \\
\hline IL-12p70 time to peak & 4.763 & 4.5704 & 1.446 & 0.249 \\
\hline IL-17A time to peak & 3.579 & 2.9097 & 4.449 & 0.019 \\
\hline IFN-y time to peak & 5.263 & 5.7595 & 1.816 & 0.178 \\
\hline IFN-a time to peak & 9.692 & 6.9364 & 1.454 & 0.247 \\
\hline TNF-a time to peak & 10.846 & 6.8577 & 1.374 & 0.266 \\
\hline & & & & 017 \\
\hline & & & \\
\hline
\end{tabular}


Table 6: Estimated Values of Logistics Parameters.

\begin{tabular}{|c|c|c|c|c|c|c|c|}
\hline \multirow{2}{*}{ Parameters } & \multirow{2}{*}{ B } & \multirow{2}{*}{$\begin{array}{l}\text { Std. } \\
\text { Error }\end{array}$} & \multirow{2}{*}{ Wald } & \multirow{2}{*}{ sig. } & \multirow{2}{*}{$\operatorname{Exp}(B)$} & \multicolumn{2}{|c|}{$\begin{array}{c}95 \% \text { Confidence Interva } \\
\text { for } \operatorname{Exp}(B)\end{array}$} \\
\hline & & & & & & $\begin{array}{l}\text { Lower } \\
\text { Bound }\end{array}$ & $\begin{array}{l}\text { Upper } \\
\text { Bound }\end{array}$ \\
\hline Mild Group & 5.080 & 1.8770 & 0.007 & 0.007 & 0.007 & 4.059 & 6364.650 \\
\hline Common Group & 7.308 & 2.1162 & 0.001 & 0.001 & 0.001 & 23.582 & 94463.486 \\
\hline $\begin{array}{l}\text { Nucleic acid turns } \\
\text { cloudy days }\end{array}$ & -0.084 & 0.1164 & 0.523 & 0.470 & 0.470 & 0.732 & 1.155 \\
\hline $\begin{array}{c}\text { CD3+T cell Peak } \\
\text { time }\end{array}$ & 0.244 & 0.1052 & 5.379 & 0.020 & 0.020 & 1.039 & 1.569 \\
\hline IL-1 $\beta$ Peak time & 0.342 & 0.1418 & 5.824 & 0.016 & 0.016 & 1.066 & 1.859 \\
\hline IL-17A Peak time & 0.164 & 0.1278 & 1.644 & 0.200 & 0.200 & 0.917 & 1.513 \\
\hline
\end{tabular}

Table 7: Differences in the Time to Peak of each Indicator between the Fast and Slow nucleic acid Seroconversion Groups.

\begin{tabular}{|c|c|c|c|c|}
\hline Indicators & Fast group ( $n=19)$ & Slow group $(n=20)$ & $t$ & sig. \\
\hline $\mathrm{CD}^{+}$cell & $7.68 \pm 4.75$ & $11.6 \pm 8.185$ & -1.838 & 0.076 \\
\hline $\mathrm{CD}^{+}{ }^{+} \mathrm{T}$ cell & $8.37 \pm 4.81$ & $13.2 \pm 7.757$ & -2.35 & $0.025^{\star}$ \\
\hline $\mathrm{CD}^{+} \mathrm{T}$ cell & $8.89 \pm 5.216$ & $10 \pm 7.827$ & -0.521 & 0.606 \\
\hline IL-1 $\beta$ & $3.39 \pm 2.81$ & $6.9 \pm 5.803$ & -2.41 & $0.023^{*}$ \\
\hline IL-2 & $3.72 \pm 2.927$ & $7.25 \pm 6.528$ & -2.185 & $0.038^{*}$ \\
\hline IL-4 & $3.39 \pm 2.789$ & $6.45 \pm 7.605$ & -1.679 & 0.106 \\
\hline IL-5 & $3.72 \pm 3.045$ & $6.4 \pm 6.411$ & -1.67 & 0.106 \\
\hline IL-6 & $3.72 \pm 2.761$ & $4.7 \pm 5.371$ & -0.694 & 0.492 \\
\hline IL-8 & $2.78 \pm 1.987$ & $6.9 \pm 7.1$ & -2.49 & $0.021^{*}$ \\
\hline IL-10 & $3.06 \pm 2.014$ & $5.3 \pm 5.695$ & -1.652 & 0.112 \\
\hline IL-12p70 & $3.28 \pm 2.296$ & $7.2 \pm 6.63$ & -2.485 & $0.02^{*}$ \\
\hline IL-17A & $3.89 \pm 3.179$ & $8.25 \pm 7.355$ & -2.413 & $0.023^{*}$ \\
\hline IFN- $\gamma$ & $2.94 \pm 1.83$ & $6.4 \pm 5.633$ & -2.596 & $0.016^{*}$ \\
\hline IFN-a & $3.33 \pm 2.473$ & $3.8 \pm 3.302$ & -0.489 & 0.628 \\
\hline TNF-a & $3 \pm 2.249$ & $7.3 \pm 7.131$ & -2.559 & $0.018^{*}$ \\
\hline
\end{tabular}

infection, type I interferon response protects alveolar epithelial cells, reduces inflammatory exudation, and ultimately improves prognosis and reducing mortality rates. The timing and intensity determine the prognosis of viral infection $[10,11]$. Channappanavar et al. infected mice with SARS-CoV and found that delayed type I interferon response resulted in an increase in proinflammatory mononuclear macrophages, leading to increased inflammatory exudation of mouse lung tissue and intensified immune response, ultimately leading to increased mortality in mice [12]. These adverse outcomes were also observed in mice infected with MERS-CoV with delayed or absent type I interferon response [13]. However, studies on the timing of immune response in clinical patients are still lacking at present. Our study is the first to show that the early onset and timely termination of the immune response has positive effects on the prognosis of disease and the speed of 2019-nCoV nucleic acid seroconversion. Patients with the above immune response may be cured before the cytokine storm occurs in the body.

There are some deficiencies in our study. Due to the lack of death cases, no in-vivo immune response was observed in the patients who were finally dead. And as a single-center retrospective study, the sample size and follow-up time is short. In the future, multicenter, prospective study is needed.
Longer follow-up period is also required to clarify the timing and strength of COVID-19 patients' immune functions, so that we accurately grasp the turning point of disease, and give timely treatment. Moreover, with the application of Next Generation Sequencing (NGS), researchers have found that the B cell receptor cluster correlats with the SARS-CoV-2 antibodies. Clonality and skewing of TCR repertoires were associated with interferon type I responses, and early $\mathrm{CD}_{4}+$ and $\mathrm{CD} 8+\mathrm{T}$ cell activation [14]. This might be a new direction of our research. In a future study, NGS may be used to analyze TCR and BCR in above three groups of patients to find out whether there are differences among them. That would be momentous in the coming era of vaccine studies.

\section{Conclusions}

The early peak, timely decrease of cytokines values and $\mathrm{T}$ cell counts in COVID-19 patients has a positive effect on prognosis. Dynamic monitoring of $\mathrm{T}$ cell counts and quantitative changes of cytokines is a simple and easy method to evaluate disease severity in clinical practice for COVID-19 patients. By closely monitoring the time and quantity changes of the above indicators, the disease turning point can be found in time, which is convenient for clinicians intervene and improve the prognosis of patients timely.

\section{References}

1. World Health Organization (2021) WHO Coronavirus Disease (COVID-19) Dashboard. Link: https://bit.ly/3dMblvr

2. Huang C, Wang Y, Li X, Ren L, Zhao J, et al. (2020) Clinical features of patients infected with 2019 novel coronavirus in Wuhan, China. Lancet 395: 497-506. Link: https://bit.ly/32DPzZT

3. National Health Commision of People's Republic of China (2020) Clinica Protocol for COVID-19, $8^{\text {th }}$ Edition. 25. Link: https://bit.ly/3aCc6dl

4. Hashimoto M, Im SJ, Araki K, Ahmed R (2019) Cytokine-Mediated Regulation of CD8 T-Cell Responses During Acute and Chronic Viral Infection. Cold Spring Harb Perspect Biol 11: a028464. Link: https://bit.ly/2QUKIAD

5. Wang $\mathrm{H}$, Zhao Q, Xiong Y, Deng L, Zhang $\mathrm{Y}$ (2020) Characteristics of Periphera Lymphocyte Subset Alteration in COVID-19 Pneumonia. J Infect Dis 221: 1762 1769. Link: https://bit.ly/3eu60x8

6. Rivino L, Lim MQ (2017) CD4+ and CD8+ T-cell immunity to Dengue lessons for the study of Zika virus. Immunology 150: 146-154. Link: https://bit.ly/2QUKR79

7. Qin C, Zhou L, Hu Z, Zhang S, Yang S, et al. (2020) Dysregulation of Immune Response in Patients With Coronavirus 2019 (COVID-19) in Wuhan, China. Clin Infect Dis 71: 762-768. Link: https://bit.ly/2PgYn4P

8. McGonagle D, Ramanan AV, Bridgewood CAO (2021) Immune cartography of macrophage activation syndrome in the COVID-19 era. Nat Rev Rheumatol 5 : 1-13. Link: https://go.nature.com/2QULOYf

9. Jamilloux Y, Henry T, Belot A, Viel S, Fauter M, et al. (2020) Should we stimulate or suppress immune responses in COVID-19? Cytokine and anti-cytokine interventions. Autoimmun Rev 19: 102567. Link: https://bit.ly/2QtLJ2X

10. Grant A, Ponia SS, Tripathi S, Balasubramaniam V, Miorin L, et al. (2016) Zika Virus Targets Human STAT2 to Inhibit Type I Interferon Signaling. Cell Host Microbe 19: 882-890. Link: https://bit.ly/3azpcbG

11. Hijano DR, Vu LD, Kauvar LM, Tripp RA, Polack FP, et al. (2019) Role of Type I Interferon (IFN) in the Respiratory Syncytial Virus (RSV) Immune Response and Disease Severity. Front Immunol 10: 566. Link: https://bit.ly/2QTJOUZ 
12. Channappanavar R, Fehr AR, Vijay R, Mack M, Zhao J, et al. (2016) Dysregulated Type I Interferon and Inflammatory Monocyte-Macrophage Responses Cause Lethal Pneumonia in SARS-CoV-Infected Mice. Cell Host Microbe 19: 181-193. Link: https://bit.ly/3epn33v

13. Channappanavar R, Fehr AR, Zheng J, Wohlford-Lenane C, Abrahante JE, et al. (2019) IFN-I response timing relative to virus replication determines
MERS coronavirus infection outcomes. J Clin Invest 129: 3625-3639. Link: https://bit.ly/3az6GQQ

14. Schulthei ßC, Paschold L, Simnica D, Mohme M, Willscher E, et al. (2020) NextGeneration Sequencing of T and B Cell Receptor Repertoires from COVID-19 Patients Showed Signatures Associated with Severity of Disease. Immunity 53: 442-455.e444. Link: https://bit.ly/3aAoD1h

\section{Discover a bigger Impact and Visibility of your article publication with}

Peertechz Publications

\section{Highlights}

* Signatory publisher of ORCID

* Signatory Publisher of DORA (San Francisco Declaration on Research Assessment)

* Articles archived in worlds' renowned service providers such as Portico, CNKI, AGRIS, TDNet, Base (Bielefeld University Library), CrossRef, Scilit, J-Gate etc.

* Journals indexed in ICMJE, SHERPA/ROMEO, Google Scholar etc.

* OAI-PMH (Open Archives Initiative Protocol for Metadata Harvesting)

* Dedicated Editorial Board for every journal

* Accurate and rapid peer-review process

* Increased citations of published articles through promotions

* Reduced timeline for article publication

Submit your articles and experience a new surge in publication services (https://www.peertechz.com/submission).

Peertechz journals wishes everlasting success in your every endeavours.

Copyright: @ 2021 Gao S, et al. This is an open-access article distributed under the terms of the Creative Commons Attribution License, which permits unrestricted use distribution, and reproduction in any medium, provided the original author and source are credited. 